\title{
Varietal Differences in Crude Protein, and Free and Hydrolyzed Amino Acid Compositions of Sweetpotato Roots
}

\author{
Yasuhiro TAKaHATA* ${ }^{*}$ Takahiro NodA ${ }^{*}$ and Tadahiro NAGATA** \\ * Crop Quality Laboratory, Department of Crop Breeding, Kyushu \\ National Agricultural Experiment Station, \\ Nishigoshi, Kumamoto $861-11$ \\ ** Present address : Food Analysis and Assessment Division, \\ National Food Research Institute, Kannondai, \\ Tsukuba, Ibaraki 305
}

\begin{abstract}
Crude protein content, and free and hydrolyzed amino acid compositions of whole root flour of sweetpotato cultivars that included lines lacking $\beta$-amylase were investigated in 1990 and 1991. A statistic varietal difference in crude protein content was detected; however, the order of the rank was largely different between the two years. The amino acid composition of whole root flour was similar among the cultivars and their profile was almost the same as in previous reports, although the aspartic acid content varied most greatly among the cultivars. The most predominant free amino acid was always asparagine in every cultivar, whereas the total free amino acid content largely varied among the cultivars. There was a large varietal difference in free asparagine content, which was quite altered between 1990 and 1991. However, the correlation coefficients between free asparagine content and hydroly zed aspartic acid content in both years were above 0.9 . Thus, most of the variabilities in aspartic acid contents among cultivars were the results of the variations in free asparagine content.
\end{abstract}

Sweetpotato is generally regarded as a highcarbohydrate, low-protein food compared with cereals. However, some genotypes of sweetpotatoes have a protein content as high as 8$9 \%$ on a dry weight basis ${ }^{1)}$, which is almost comparable to that of cereals. Moreover, the nutritional value of the sweetpotato protein has been reported to be excellent ${ }^{1{ }^{12}}$ based on the amino acid composition.

Varietal differences in crude protein contents have been reported to be $1.3-10 \%$ (dry weight basis) by WALTER et al. ${ }^{3)}$. On a fresh weight basis, the total protein of six American cultivars grown under identical conditions and analyzed immediately after harvest ranged from $1.36-2.13 \%{ }^{4}$ ). Variations in total protein contents within cultivars have also been studied by several groups. One group ${ }^{5)}$ found that the variation was slightly less, and another ${ }^{6}$ found that it was as great among roots from the same plant as between plants. High field-to-field and location variabilities have also been noted for cultivars ${ }^{5)}$. The varietal differences in the amino acid composition were also extensively studied by some

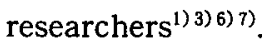

However, there have been only a few reports on the protein contents and the amino acid compositions of Japanese cultivars ${ }^{2 / 8)}$. The data may not be sufficient to be reported at present because the data have been obtained from only one or two old cultivars. Moreover, a new cultivar lacking $\beta$-amylase was recently released for processing purpose ${ }^{9)}$, but the amino acid composition of this new cultivar has not been clarified yet. Thus, including the lines lacking $\beta$-amylase, analysis of the proteins and amino acids of greater numbers of sweetpotato cultivars of Japan is greatly needed.

On the other hand, Purcell and Walter ${ }^{10)}$ reported the composition of non-protein nitrogen using the Jewel cultivar after 107 days of storage. PuRcell et al. ${ }^{11)}$ also reported that 
amino acid composition varied significantly between the "syrup" fraction and the "protein" fraction. However, the free amino acid composition immediately after harvest has not been reported, and the varietal differences in that is still not evident. More studies on the differences in free amino acid contents of sweetpotatoes among varieties should be carried out.

In the present study, we investigated the varietal differences in crude protein content, free amino acid content and amino acid composition of sweetpotato roots to shed more light on the protein content and the amino acid composition of sweetpotato cultivars. The materials used in this study consisted mainly of Japanese cultivars including the lines lacking $\beta$-amylase.

\section{Materials and Methods}

\section{Samples}

All sweetpotato roots used in this study were grown in a field at Nishigoshi, Kumamoto, Japan. Immediately after harvest, each root was freeze-dried and milled until it passed through a $500 \mu \mathrm{m}$ sieve. All samples were stored at $-30^{\circ} \mathrm{C}$ until analysis. Each datum was estimated by at least duplicate measurements.

\section{Nitrogen analysis}

The nitrogen content of the flour samples was determined by the macro-Kjeldahl method with least two replicate analyses. Protein content was calculated to be $\mathrm{N} \times 6.25$. In 1990, the flour samples derived from three roots per each line were mixed and analyzed to assess the range in varietal difference. To investigate the variability within cultivars, nitrogen content was separately determined on three roots per each line using several representative Japanese cultivars in 1990 and 1991.

\section{Amino acid analysis}

Hydrolyzed and free amino acids were analyzed using the flour samples mixed from three roots in both years. In addition, samples oxidized with performic acid were also hydrolyzed for the determination of sulfur amino acids in the first year. In the determi-
Table 1 Crude protein contents of 46 sweetpotato cultivars in 1990

\begin{tabular}{|c|c|}
\hline Cultivar name & $\begin{array}{l}\text { Crude protein } \\
\text { (\%, dry basis) }\end{array}$ \\
\hline Tsurusengan & 9.22 \\
\hline Beniwase & 7.06 \\
\hline Kyukei 114 & 6.84 \\
\hline Bougainville & 6.84 \\
\hline Benihayato & 6.75 \\
\hline Iigou & 6.73 \\
\hline Norin 2 & 6.68 \\
\hline Kyukei 123 & 6.45 \\
\hline Kyushu 105 & 6.13 \\
\hline Unit 1 Port Rico & 5.97 \\
\hline Ariakeimo & 5.89 \\
\hline Gifu 1 & 5.85 \\
\hline Kenroku & 5.81 \\
\hline Georgia Jet & 5.73 \\
\hline Kyushu 91 & 5.58 \\
\hline Chicago & 5.58 \\
\hline Shiroyutaka & 5.45 \\
\hline Chugoku 25 & 5.45 \\
\hline Kyushu 104 & 5.40 \\
\hline Kyusyu 89 & 5.32 \\
\hline Kyushu 97 & 5.29 \\
\hline Yellow Butter & 5.28 \\
\hline Beniotome & 5.24 \\
\hline Satsumahikari & 5.20 \\
\hline Kyukei 124 & 5.19 \\
\hline Okinawa 105 & 4.99 \\
\hline Tainong 16 & 4.86 \\
\hline Shirosatsuma & 4.83 \\
\hline Chugoku 37 & 4.71 \\
\hline Kyushu 106 & 4.66 \\
\hline Kyushu 101 & 4.65 \\
\hline Oiransaitama 1 & 4.56 \\
\hline Benikomachi & 4.52 \\
\hline Yoshida & 4.49 \\
\hline Beniazuma & 4.47 \\
\hline Philippine & 4.47 \\
\hline Beniaka & 4.44 \\
\hline Tinian & 4.39 \\
\hline Koganesengan & 4.32 \\
\hline Kyushu 95 & 4.30 \\
\hline Tachikagoshima & 4.29 \\
\hline Kokei 14 & 4.27 \\
\hline Murasakibaru 2 & 4.06 \\
\hline Chushi 3 & 3.88 \\
\hline Toukai 5 & 3.79 \\
\hline Murasakibaru 3 & 2.89 \\
\hline
\end{tabular}

Crude protein : Kjeldahl $\mathrm{N} \times 6.25$.

$1.5 \mathrm{~g}$ of whole root flour was used for analysis. 
nation of hydrolyzed amino acid content, 100 $\mathrm{mg}$ of flour sample (for sulfur amino acids, samples oxidized by performic acid were used) was hydrolyzed with $6 \mathrm{~N}-\mathrm{HCl}$ containing $0.02 \%$ 2 -mercaptoethanol at $110^{\circ} \mathrm{C}$ under vacuo for 24 h. Each hydrolyzed sample was filtered and filled to constant volume. An aliquot of the filtrate was evaporated and redissolved with sodium citrate buffer $(\mathrm{pH} 2.2)$. Free amino acids were extracted with $80 \%$ ethanol and filtered. An aliquot of the filtrate was evaporated and redissolved with lithium citrate buffer $(\mathrm{pH} 2.2)$. The following procedures were performed on HPLC as directed by the manufacturer. Identification of each HPLC peak was based on the retention times using authentic standards.

\section{Results and Discussion}

The crude protein contents of 46 lines are listed in Table 1. The protein content of the various lines ranged from 2.89 to $9.22 \%$. Most lines contained between 4-7\% protein, which was almost the same as the range reported by PURCELl et al. ${ }^{1)}$. The variability range of the protein content of the Japanese cultivars was not different from those of other regions. Three lines lacking $\beta$-amylase, Satsumahikari, Kyushu 89 and Chugoku 37, did not show a specific character in their crude protein content.

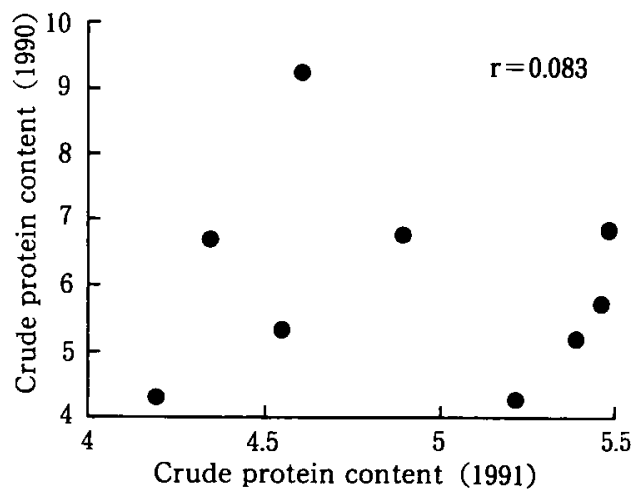

Fig. 1 Scattergram of crude protein contents between 1990 and 1991

Table 2 Within cultivar differences of crude protein contents of several sweetpotato cultivars in 1990 and 1991

\begin{tabular}{lcc}
\hline \multirow{2}{*}{ Cultivar name } & \multicolumn{2}{c}{ Crude protein content } \\
\cline { 2 - 3 } & 1990 & 1991 \\
\hline Norin 2 & $6.68 \pm 0.768(11.5)$ & $4.34 \pm 0.746(17.2)$ \\
Beniwase & $7.06 \pm 1.25(17.7)$ & N.D. \\
Koganesengan & $4.32 \pm 0.359(8.3)$ & $4.19 \pm 1.37(32.7)$ \\
Tsurusengan & $9.22 \pm 1.36(14.7)$ & $4.61 \pm 0.636(13.8)$ \\
Benihayato & $6.75 \pm 0.500(7.4)$ & $4.89 \pm 0.738(15.1)$ \\
Shiroyutaka & N.D. & $5.26 \pm 0.362(6.9)$ \\
Satsumahikari & $5.20 \pm 0.718(13.8)$ & $5.38 \pm 0.872(16.2)$ \\
Kyushu 89 & $5.32 \pm 0.473(8.9)$ & $4.55 \pm 0.783(17.2)$ \\
Beniotome & N.D. & $6.90 \pm 0.987(14.3)$ \\
Kyukei 114 & $6.84 \pm 1.15(16.8)$ & N.D. \\
Kokei 14 & $4.27 \pm 0.418(9.8)$ & $5.22 \pm 0.840(16.1)$ \\
Murasakibaru 3 & $2.89 \pm 0.364(12.6)$ & N.D. \\
Tachikagoshima & N.D. & $3.46 \pm 0.100(2.9)$ \\
Yellow butter & N.D. & $3.67 \pm 0.829(22.6)$ \\
Bougainville & $6.84 \pm 2.38(34.8)$ & $5.48 \pm 1.69(30.9)$ \\
Georgia Jet & $5.73 \pm 0.269(4.7)$ & $5.46 \pm 0.895(16.4)$ \\
Kyushu 108 & N.D. & $3.61 \pm 0.881(24.4)$ \\
\hline
\end{tabular}

Crude protein content : \%, (dry weight basis) \pm SD (coefficient of variance).

N.D. : Not determined. 
The coefficient of variance (CV) of the protein content among roots within each cultivar ranged from $4.7 \%$ to $34.8 \%$ in 1990 and from $2.94 \%$ to $32.7 \%$ in 1991 (Table 2). The variability was almost the same as that found by other researchers ${ }^{56)}$. A statistic varietal difference was detected in both years; however, the order of the rank in the crude protein content was greatly different between 1990 and 1991 (Fig. 1).
The correlation coefficient of crude protein contents between 1990 and 1991 was 0.083 . BRADBURY et $a l .^{6)}$ also showed that year-to-year correlation of crude protein content was not significant ( $r=0.393$, calculated by present authors using the data of Upper Mendi). Compared with the correlation of free sugar content between the two years ${ }^{12)}$, the correlation of crude protein content was obviously

Table 3 Amino acid contents of 8 sweetpotato cultivars in 1990 and 1991

\begin{tabular}{|c|c|c|c|c|c|c|c|c|c|c|}
\hline & $\begin{array}{c}\text { Kogane- } \\
\text { sengan }\end{array}$ & $\begin{array}{l}\text { Tsuru- } \\
\text { sengan }\end{array}$ & $\begin{array}{l}\text { Beni- } \\
\text { hayato }\end{array}$ & $\begin{array}{c}\text { Shiroyu- } \\
\text { taka }\end{array}$ & $\begin{array}{c}\text { Satsuma- } \\
\text { hikari }\end{array}$ & $\begin{array}{c}\text { Kyushu } \\
89\end{array}$ & $\begin{array}{c}\text { Benio- } \\
\text { tome }\end{array}$ & Kokei 14 & Mean & C.V. \\
\hline \multicolumn{11}{|l|}{1990} \\
\hline Alanine & 281 & 273 & 286 & 246 & 273 & 297 & 258 & 274 & 274 & 6.0 \\
\hline Arginine & 282 & 278 & 289 & 252 & 243 & 280 & 224 & 260 & 264 & 8.9 \\
\hline Aspartic acid & 998 & 1762 & 1226 & 1026 & 1521 & 1014 & 1025 & 1167 & 1217 & 24.0 \\
\hline Glutamic acid & 619 & 556 & 617 & 550 & 582 & 679 & 501 & 671 & 597 & 10.7 \\
\hline Glycine & 263 & 254 & 266 & 248 & 234 & 272 & 247 & 248 & 254 & 5.0 \\
\hline Histidine & 142 & 140 & 167 & 139 & 149 & 140 & 139 & 173 & 149 & 9.5 \\
\hline Proline & 218 & 217 & 226 & 302 & 205 & 320 & 310 & 211 & 251 & 20.6 \\
\hline Serine & 325 & 332 & 325 & 269 & 293 & 364 & 270 & 294 & 309 & 11.1 \\
\hline Threonine & 295 & 305 & 303 & 265 & 273 & 343 & 265 & 303 & 294 & 9.2 \\
\hline Valine & 388 & 437 & 415 & 353 & 363 & 437 & 357 & 363 & 389 & 9.6 \\
\hline Isoleucine & 268 & 265 & 273 & 238 & 253 & 300 & 245 & 253 & 262 & 7.7 \\
\hline Leucine & 392 & 365 & 400 & 330 & 352 & 396 & 343 & 374 & 369 & 7.3 \\
\hline Lysine & 316 & 296 & 320 & 275 & 269 & 316 & 265 & 303 & 295 & 7.9 \\
\hline Total sulfur & 191 & 216 & 229 & 185 & 163 & 189 & 220 & 200 & 199 & 11.3 \\
\hline Total aroma & 547 & 589 & 585 & 612 & 543 & 593 & 574 & 498 & 568 & 6.6 \\
\hline \multicolumn{11}{|l|}{1991} \\
\hline Alanine & 255 & 267 & 258 & 250 & 251 & 239 & 263 & 270 & 257 & 4.1 \\
\hline Arginine & 218 & 264 & 278 & 262 & 243 & 236 & 262 & 228 & 249 & 8.6 \\
\hline Aspartic acid & 853 & 884 & 804 & 997 & 1241 & 653 & 1351 & 1444 & 1028 & 28.7 \\
\hline Glutamic acid & 576 & 473 & 465 & 569 & 488 & 437 & 548 & 620 & 522 & 12.9 \\
\hline Glycine & 233 & 256 & 262 & 255 & 249 & 262 & 253 & 250 & 253 & 3.8 \\
\hline Histidine & 183 & 159 & 160 & 160 & 152 & 140 & 146 & 169 & 159 & 8.8 \\
\hline Proline & 209 & 229 & 298 & 271 & 336 & 324 & 238 & 195 & 263 & 20.9 \\
\hline Serine & 286 & 307 & 266 & 284 & 274 & 276 & 298 & 291 & 285 & 4.9 \\
\hline Threonine & 268 & 288 & 260 & 278 & 273 & 258 & 288 & 295 & 276 & 5.1 \\
\hline Valine & 353 & 378 & 353 & 363 & 357 & 353 & 372 & 366 & 362 & 2.7 \\
\hline Isoleucine & 248 & 250 & 255 & 250 & 253 & 243 & 260 & 270 & 253 & 3.5 \\
\hline Leucine & 365 & 365 & 370 & 356 & 352 & 321 & 378 & 422 & 366 & 8.0 \\
\hline Lysine & 286 & 252 & 292 & 323 & 252 & 258 & 289 & 275 & 278 & 9.1 \\
\hline \multicolumn{11}{|l|}{ Total sulfur } \\
\hline Total aroma & 547 & 578 & 536 & 585 & 547 & 536 & 589 & 581 & 562 & 4.2 \\
\hline
\end{tabular}

All figures were calculated as $\mathrm{mg}$ of amino acid/g of $\mathrm{N}$. CV : Coefficient of variance. 
weak. Thus, these results show the unstable nature of the crude protein content of sweetpotato roots.

In the hydrolyzed amino acid analysis, the aspartic acid contents mostly varied among cultivars (Table 3 ). The far right column shows the mean and CV of eight cultivars. The $\mathrm{CV}$ of the aspartic acid content was largest among the amino acids; that indicates more variability in aspartic acid than in other amino acids. Furthermore, the profile of the varietal difference in aspartic acid content was different between the two years, i.e., Tsurusengan and Satsumahikari were high in the first year, and Satsumahikari, Beniotome and Kokeil4 were high in the second year. The CV of the proline content was second largest in both years; however, this resulted from the low sensitivity of OPA-proline in the determination. The other amino acid contents of whole flour of each cultivar were almost similar because the $\mathrm{CV}$ of each amino acid was relatively small.

Generally, the storage root of sweetpotato has two kinds of predominant protein, sporamin and $\beta$-amylase. Sporamin comprises $60-80 \%$ of the total proteins and $\beta$-amylase ca. $5 \%^{1314)}$. Considering this protein composition of sweetpotato root, the lines lacking $\beta$-amylase were expected to have different amino acid composition. In this experiment, however, there was no large difference in amino acid composition among the Japanese cultivars including the lines lacking $\beta$-amylase, compared with the data obtained from US. cultivars ${ }^{1)}{ }^{15)}$ and from Papua New Guinea cultivars ${ }^{6) 7}$

Amino acid scores are shown in Table 4. Many authors have previously assessed the quality of sweetpotato protein by comparing it with a hypothetical reference protein (FAO/ WHO, 1973). WALTER et al. ${ }^{3)}$ reported that total sulfur was always limiting, and leucine and lysine were limiting in most whole flour samples of sweetpotato cultivars. NAGASE ${ }^{2)}$ reported no limiting amino acids for the protein isolated from an unnamed Japanese cultivar. TAIRA and TAIRA $^{8)}$ reported a varietal difference in the tyrosine and arginine content of hydrolyzed whole root flour. In the present

Table 4 Amino acid scores of 8 sweetpotato cultivars in 1990 and 1991

\begin{tabular}{|c|c|c|c|c|c|c|c|c|}
\hline & $\begin{array}{c}\text { Kogane- } \\
\text { sengan }\end{array}$ & $\begin{array}{l}\text { Tsuru- } \\
\text { sengan }\end{array}$ & $\begin{array}{c}\text { Beni- } \\
\text { hayato }\end{array}$ & $\begin{array}{l}\text { Shiro- } \\
\text { yutaka }\end{array}$ & $\underset{\text { hatsuma- }}{\text { hikari }}$ & Kyushu 89 & $\begin{array}{c}\text { Beni- } \\
\text { otome }\end{array}$ & Kokei 14 \\
\hline \multicolumn{9}{|l|}{1990} \\
\hline Threonine & 1.18 & 1.22 & 1.21 & 1.06 & 1.09 & 1.37 & 1.06 & 1.21 \\
\hline Valine & 1.25 & 1.41 & 1.34 & 1.14 & 1.17 & 1.41 & 1.15 & 1.17 \\
\hline Isoleucine & 1.07 & 1.06 & 1.09 & 0.95 & 1.01 & 1.20 & 0.98 & 1.01 \\
\hline Leucine & 0.89 & 0.83 & 0.91 & 0.75 & 0.80 & 0.90 & 0.78 & 0.85 \\
\hline Lysine & 0.93 & 0.87 & 0.94 & 0.81 & 0.79 & 0.93 & 0.78 & 0.89 \\
\hline Total sulfur & 0.87 & 0.98 & 1.04 & 0.84 & 0.74 & 0.86 & 1.00 & 0.91 \\
\hline Total aroma & 1.44 & 1.55 & 1.54 & 1.61 & 1.43 & 1.56 & 1.51 & 1.31 \\
\hline \multicolumn{9}{|l|}{1991} \\
\hline Threonine & 1.07 & 1.15 & 1.04 & 1.11 & 1.09 & 1.03 & 1.15 & 1.18 \\
\hline Valine & 1.14 & 1.22 & 1.14 & 1.17 & 1.15 & 1.14 & 1.20 & 1.18 \\
\hline Isoleucine & 0.99 & 1.00 & 1.02 & 1.00 & 1.01 & 0.97 & 1.04 & 1.08 \\
\hline Leucine & 0.83 & 0.83 & 0.84 & 0.81 & 0.80 & 0.73 & 0.86 & 0.96 \\
\hline Lysine & 0.84 & 0.74 & 0.86 & 0.95 & 0.74 & 0.76 & 0.85 & 0.81 \\
\hline \multicolumn{9}{|l|}{ Total sulfur } \\
\hline Total aroma & 1.44 & 1.52 & 1.41 & 1.54 & 1.44 & 1.41 & 1.55 & 1.53 \\
\hline
\end{tabular}

All figures were calculated by comparing them with a hypothetical reference protein (FAO/WHO, 1973). 
study, leucine and lysine were always limited ; however, total sulfur amino acids of two cultivars (Benihayato and Beniotome) were not limited in 1990. Especially, Benihayato also showed a relatively good amino acid composition (the limiting amino acid was leucine ; 84\%) in 1991, although sulfur amino acids were not determined. Considering the high $\beta$-carotene content of Benihayato ${ }^{16)}$, this cultivar is thought to be a useful cultivar based on nutritional aspects.

Table 5 shows the free amino acid content of each cultivar. Asparagine, aspartic acid and glutamic acid were predominant, and other amino acid contents were similar and less than $2 \mu \mathrm{mol} / \mathrm{g}$ (dry weight basis; data are not shown) in all the cultivars. The most predominant free amino acid was always asparagine in every cultivar, whereas the total free amino acid content varied greatly among the cultivars. The increase in total free amino acid content depended greatly on the increase in free asparagine content. This corresponds well to the report by PURCELl and WALTER ${ }^{10)}$ that free asparagine was the largest constituent of the free amino acids in the sweetpotato roots. In the present study, we show the varietal difference in free asparagine content; however, the profile of its varietal difference was very much changed between 1990 and 1991, i.e., Tsurusengan and Satsumahikari were high in 1990, and Satsumahikari, Beniotome and Kokei14 were high in 1991. Interestingly, this varietal difference was almost the same as
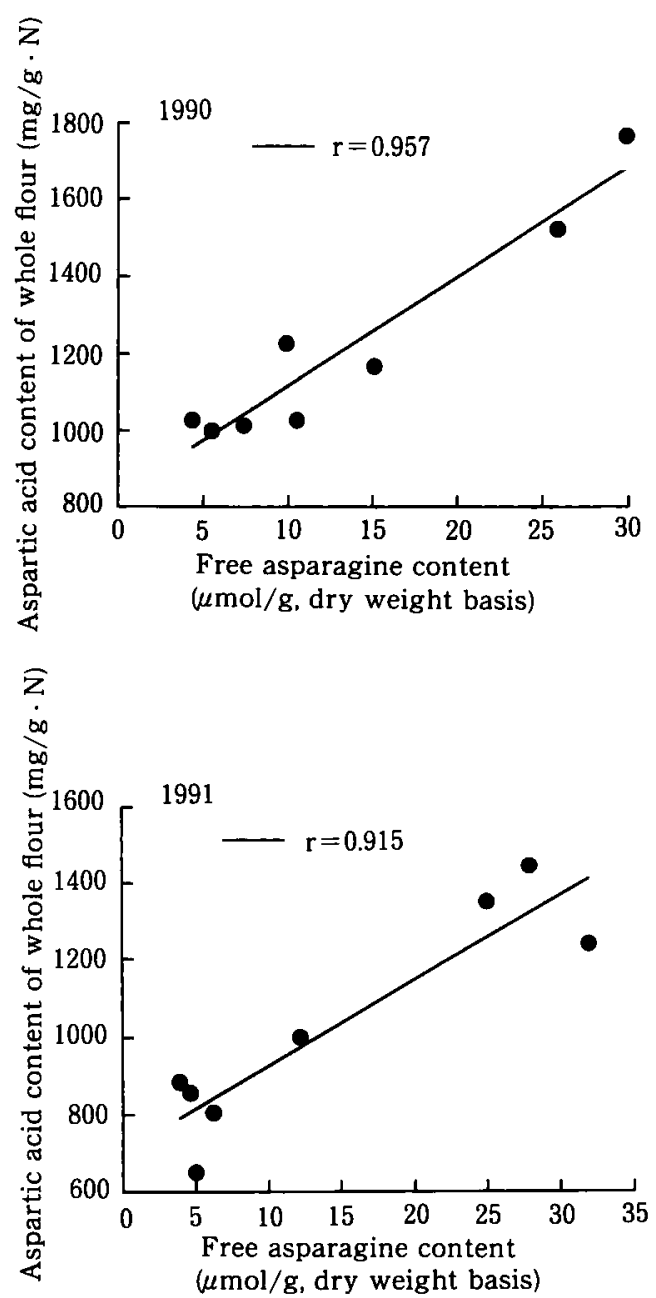

Fig. 2 Scattergrams of free asparagine content and hydrolyzed aspartic acid content in 1990 and 1991

Table 5 Free amino acid contents of 8 sweetpotato cultivars in 1990 and 1991

\begin{tabular}{lcrrrrrrr}
\hline \hline & $\begin{array}{c}\text { Kogane- } \\
\text { sengan }\end{array}$ & $\begin{array}{c}\text { Tsuru- } \\
\text { sengan }\end{array}$ & $\begin{array}{c}\text { Beni- } \\
\text { hayato }\end{array}$ & $\begin{array}{c}\text { Shiro- } \\
\text { yutaka }\end{array}$ & $\begin{array}{c}\text { Satsuma- } \\
\text { hikari }\end{array}$ & Kyushu 89 & $\begin{array}{c}\text { Beni- } \\
\text { otome }\end{array}$ & Kokei 14 \\
\hline 1990 & & & & & & & & \\
Asparagine & 5.5 & 29.8 & 9.9 & 4.4 & 25.8 & 7.4 & 10.5 & 15.1 \\
Aspartic acid & 3.4 & 3.9 & 5.2 & 3.1 & 2.5 & 3.3 & 2.8 & 4.6 \\
Glutamic acid & 2.9 & 3.3 & 4.9 & 4.8 & 3.4 & 3.6 & 2.2 & 4.4 \\
\hline 1991 & & & & & & & & \\
Asparagine & 4.6 & 3.9 & 6.2 & 12.1 & 32.0 & 5.0 & 25.0 & 28.0 \\
Aspartic acid & 4.0 & 3.9 & 5.0 & 5.5 & 4.8 & 2.3 & 4.3 & 6.7 \\
Glutamic acid & 3.6 & 0.8 & 2.6 & 7.8 & 2.8 & 3.5 & 6.3 & 6.5 \\
\hline
\end{tabular}

All figures were calculated as $\mu \mathrm{mol} / \mathrm{g}$ on a dry weight basis. 
that of hydrolyzed aspartic acid content. Fig. 2 shows the scattergrams of free asparagine content and hydrolyzed aspartic acid content in both years. The correlation coefficients were 0.957 in 1990 and 0.915 in 1991 . Thus, it is revealed that the largest variability in aspartic acid content among cultivars was the result of the variability in free asparagine content.

\section{Acknowledgment}

We are grateful to Dr. T. Suzuki for his valuable advice on this work. We also thank Mr. M. NAKASHIMA and Ms. H. HAYASE for their excellent technical assistance. The work was partially supported by a grant from the Science and Technology Agency (STA), Japan.

\section{References}

1) Purcell, A.E., Swaisgood, H.E. and Pope, D.T. : J. Amer. Soc. Hort. Sci., 97, 30 (1972).

2) NAGASE, T.: Fukuoka Igaku Zassi., 48, 1828 (1957).

3) Walter, W.M., Collins, W.W. and Purcell A. E. : J. Agric. Food Chem., 32, 695 (1984).

4) Picha, D.H. : J. Food Sci., 50, 1768 (1985).

5) Purcell, A.E., Walter, W.M. and Giesbrecht, F.G. : J. Agric. Food Chem., 26, 362 (1978).

6) Bradbury, J.H., Hammer, B., NGuYen, T., ANDERs, M. and Miller, J.S.: J. Agric. Food Chem., 33, 281 (1985).

7) Bradbury, J.H., Baines, J., Hammer, B., ANDERS, M. and Miller, J.S. : J. Agric. Food Chem., 32, 468 (1984).

8) TAIRA, H. and TaiRA, H. : Eiyo to Shokuryo, 15, 30 (1963).

9) KuKImURA, H., Yoshida, T. and KomaKi, K.: JARQ, 22, 7 (1985).

10) Purcell, A.E. and Walter, W.M.: J. Agric. Food Chem., 28, 842 (1980).

11) Purcell, A.E., Walter, W.M. and Giesbrecht, F.G. : J. Agric. Food Chem., 26, 699 (1978).
12) Takahata, Y., Noda, T. and Nagata, T. : Jap. d. Breed., 42, 515 (1992).

13) Maeshima, M., Sasaki, T. and AsahI, T.: Phytochemistry, 24, 1899 (1985).

14) Nakamura, K., Ohto, M., Yoshida, N. and Nakamura K. : Plant Physiol., 96, 902 (1991).

15) Walter W.M., Catignani, G.L., Yow, L.L. and PORTER, D.H. : J. Agric. Food Chem., 31, 947 (1983).

16) Takahata, Y., Noda, T. and Nagata, T : Jap. J. Breed., 43, 421 (1993).

(Received May 16, 1994)

\section{サッマイモの粗蛋白含量およひ遊離・加水分解 アミノ酸組成の品種間差異}

$$
\begin{gathered}
\text { 高畑康浩* - 野田高弘* ・永田忠博** } \\
{ }^{*} \text { 農林水産省九州農業試験場 } \\
\text { （干861-11 熊本県西合志町須屋 2421） } \\
\quad \text { ** 現）農林水産省食品総合研究所 } \\
\text { （干305 茨城県つくば市観音台 2-1-2） }
\end{gathered}
$$

サッマイモ塊根の粗蛋白含量および遊離・加水分解了 ミ／酸組成の品種間差異を 2 か年にわたり調查した，材 料として近年育成された $\beta$-アミラーゼ欠損系統も含め た. 粗蛋白含量については単一の年度内では品種間差が 認められたが, 年次間の傾向は大きく異なり不安定で あった．加水分解了ミノ酸の組成においては了スパラギ ン酸含量の品種間差が大きく，その年次間の傾向は大き く異なった，その他のアミノ酸については品種間でほぼ 同様であり，年次間比較です組成としての大差はなかっ た. すなわち， $\beta$-アミラーゼ久損系統も含めて，塊根の 粗蛋白含量・アミノ酸組成には，年次間で安定した大き な品種間差は無かった，遊離アミノ酸についてはほとん どの品種でアスパラギンが最も多く含まれ大きな品種・ 年次間差か諰められたが，この傾向は加水分解了ミ/酸 の組成におけるアスパラギン酸含量の品種・年次間差と よく一致した. 